CLINICAL STUDY

\title{
Leptin response to endogenous acute stress is independent of pituitary function
}

Urs Schafroth, Kristin Godang, Thor Ueland and Jens Bollerslev

Department of Endocrinology, National University Hospital, Oslo, Norway

(Correspondence should be addressed to Urs Schafroth, Department of Endocrinology, National University Hospital, Sognsvannsveien 20, 0027 Oslo, Norway; Email: urs.schafroth@rikshospitalet.no)

\begin{abstract}
There are close interactions between the adipocyte-derived hormone, leptin, and the anterior pituitary, especially the hypothalamic-pituitary-adrenal (HPA) axis. We investigated the relationship between the sympathetic adrenergic system and serum leptin levels, dependent on the function of anterior pituitary hormone axes, in 27 patients without a history of a hormone-secreting pituitary adenoma or other underlying endocrine disease. Based on responses in a routine insulin hypoglycemia test (ITT), the patients were classified as hypopituitary (HP; $n=15$ ), growth hormone deficient (GHD; $n=6$ ) or controls (CTR; 6 patients with normal responses).

Nadir plasma glucose was $1.5 \pm 0.1 \mathrm{mmol} / \mathrm{l}$ at the time of maximum hypoglycemia. Each group had a significant increase in plasma epinephrine; however the magnitude of change was significantly higher in GHD $(6.066 \pm 1.633 \mathrm{nmol} / \mathrm{l})$ compared with HP patients $(1.781 \pm 0.492 \mathrm{nmol} / \mathrm{l})(P<0.01)$. The rise in norepinephrine was delayed $(60 \mathrm{~min})$ in the HP and CTR groups. However, in GHD patients there was a considerable increase at the time of hypoglycemia which was significantly different from HP $(P<0.001)$ and CTR $(P<0.05)$ patients. The increase in catecholamines was followed by a quick and significant decrease in serum leptin levels 45 min after an i.v. bolus injection of insulin in HP patients $(-4.7 \pm 2.5 \%, P<0.05)$, which was significantly sustained after $60 \mathrm{~min}(-5.6 \pm 2.5 \%, P<0.05)$. In CTR patients there was a significant decrease in serum leptin levels $60 \mathrm{~min}$ after i.v. insulin $(-14.4 \pm 6.9 \%, P<0.05)$, while no significant response was observed in the GHD group, although 5 of 6 patients had decreased levels at 45 and 60 min. No differences between the groups were found by ANOVA.

In conclusion, an acute increase in endogenous circulating catecholamines is associated with a quick decrease in serum leptin levels. Intact anterior pituitary function seems not to be essential for this hitherto poorly understood mechanism.
\end{abstract}

European Journal of Endocrinology 145 295-301

\section{Introduction}

Leptin, the ob-gene product, is a peptide hormone derived from adipocytes and is involved in the regulation of food intake (1). However, expression at low levels has recently been demonstrated in other tissues $(2,3)$. Plasma concentrations of leptin are positively correlated to body mass index (4), with higher levels in women than in men (5).

Recently, a close relationship between leptin and the anterior pituitary endocrine axes has been demonstrated. Leptin levels are pulsatile and are inversely related to pituitary-adrenal function (6), with a diurnal peak at around midnight $(7,8)$. Glucocorticoids enhance leptin levels (9), partially independent of alterations in total body fat mass (10), while adrenocorticotropic hormone (ACTH) and central activation of the hypothalamic-pituitary-adrenal (HPA) axis does not alter plasma leptin concentrations acutely (11). A functional leptin receptor has recently been demonstrated in human cortical and medullary adrenal tissue (12). In physiological doses, growth hormone (GH) does not seem to alter serum leptin levels acutely $(13,14)$ and the circadian rhythm of leptin is preserved in $\mathrm{GH}$ deficient (GHD) patients $(15,16)$. Substitution with GH to GHD adults is followed by a decrease in leptin levels secondary to changes in body composition and reduced total body fat mass (17). Estradiol and testosterone have complementary effects on leptin levels, resulting in the above mentioned gender differences (5). The relationship between adipocyte-derived leptin and the hypothalamic-pituitary-thyroid axis is more complex due to interactions at several levels $(18,19)$, and there are few studies addressing this question in pituitary disorders. 
Similarly, current knowledge of the relationship between leptin and the sympathetic nervous system is still limited, and the results of recent research are controversial. Human plasma leptin concentrations are temporarily suppressed by infusion of the beta-adrenergic agonist isoprenaline $(20,21)$. However, a corresponding effect could not be demonstrated for endogenous alterations in plasma catecholamines after treatment with a catecholamine synthese inhibitor (22), and there is a lack of leptin suppression in patients with pheochromocytoma (23). Furthermore, surgically induced acute stress response resulted in a rapid decrease in plasma leptin levels parallel to an increase in cortisol levels (24).

In this study, we investigated (i) the physiological relationship between the sympathetic adrenergic system and serum leptin levels, and (ii) the dependence of these interactions on the proper function of the anterior pituitary. For this purpose, we evaluated patients with impaired pituitary function and compared them with patients with intact hormonal axes during acute, hypoglycemia-induced stress (insulin tolerance test $=$ ITT).

\section{Subjects and methods}

\section{Subjects}

We studied consecutive patients with suspected or proven pituitary disease. An ITT was performed as part of the routine assessment of pituitary function in all patients aged $<60$ years, and without a history of epilepsy or cardiac disease $(n=59)$. Subjects with hormone-secreting pituitary adenoma (previously acromegaly $(n=10)$, Cushing's disease $(n=6)$, prolactinoma $(n=1)$ and thyrotropin secreting adenoma $(n=1))$ were excluded, as were subjects with other underlying endocrine or metabolic disorders (1 patient with primary hyperparathyroidism and 1 with primary hyperaldosteronism, 2 patients with diabetes mellitus) and patients with inadequate hypoglycemia (plasma glucose $\geq 2.2 \mathrm{mmol} / \mathrm{l} ; n=6$ ). The ITTs of the remaining 31 patients were analyzed for the maximal responses in the somatotrope and corticotrope hormone affected axes, according to the following definition: $\mathrm{GH}<10 \mathrm{mU} / \mathrm{l}$ and/or cortisol $<500 \mathrm{nmol} /$ =impaired response. Patients with normal GH response but impaired cortisol response $(n=4)$ were not analyzed further because of the low number of individuals in this group. The remaining 27 patients were divided into three groups: (i) hypopituitary (HP), patients with impaired responses in both the somatotrope and corticotrope hormone axes $(n=15)$, (ii) growth hormone deficient (GHD), patients who had impaired responses in the somatotrope axis but normal responses in the corticotrope axis $(n=6)$, and (iii) controls (CTR), patients who had normal responses in both axes $(n=6)$ (Table 1$)$. There were no significant differences in body mass index (BMI) or gender between

Table 1 Clinical characteristics of patients with hypopituitarism (HP), growth hormone deficiency (GHD) and controls.

\begin{tabular}{|c|c|c|c|c|}
\hline & HP & GHD & Controls & $\boldsymbol{P}$ \\
\hline Number $(n)$ & 15 & 6 & 6 & \\
\hline Age (years) (mean \pm S.E.M.) & $43 \pm 3$ & $39 \pm 7$ & $33 \pm 7$ & NS \\
\hline \multicolumn{5}{|l|}{ Sex } \\
\hline Women $(n)$ & 7 & 2 & 3 & \\
\hline Men $(n)$ & 8 & 4 & 3 & \\
\hline BMI $\left(\mathrm{kg} / \mathrm{m}^{2}\right)$ (mean \pm s.E.M.) & $27 \pm 1$ & $25 \pm 2$ & $23 \pm 2$ & NS \\
\hline \multicolumn{5}{|l|}{ Etiology $(n)$} \\
\hline Non-secreting pituitary adenoma & 7 & 2 & 2 & \\
\hline Craniopharyngioma $^{1}$ & 2 & 1 & & \\
\hline Parasellar meningeoma & & 1 & & \\
\hline Ependymoma (III: Ventricle) & 1 & & & \\
\hline Rathke's cleft cyst & 1 & 1 & 1 & \\
\hline Empty sella & 2 & & & \\
\hline Neurosarcoidosis & 1 & & & \\
\hline Sheehan's syndrome & 1 & & & \\
\hline Post meningitis ( $>1$ year) & & & 2 & \\
\hline Idiopathic isolated gonadotropin deficiency & & & 1 & \\
\hline Late puberty & & 1 & & \\
\hline \multicolumn{5}{|l|}{ Hormone substitution } \\
\hline Cortisone acetate ${ }^{2}$ & 12 & 1 & 2 & \\
\hline Levothyroxine & 6 & 1 & 1 & \\
\hline Estradiol & 1 & 0 & 1 & \\
\hline Testosterone & 2 & 1 & 1 & \\
\hline Human growth hormone & 0 & 0 & 0 & \\
\hline Vasopressin & 1 & 0 & 0 & \\
\hline No substitution & 1 & 3 & 1 & \\
\hline
\end{tabular}

${ }^{1}$ One patient postradiotherapy; ${ }^{2}$ withdrawn at least $48 \mathrm{~h}$ prior to ITT. NS, not significant. 
the three groups. If necessary, $\mathrm{HP}$ and GHD patients were adequately treated with thyroxine and/or sex steroids prior to the ITT. Cortisone substitution was withdrawn at least $48 \mathrm{~h}$ prior to the test in all patients.

\section{Methods}

An insulin tolerance test was performed at $0900 \mathrm{~h}$ after a 10-h overnight fast as part of the routine assessment of pituitary function. The patients were recumbent for $30 \mathrm{~min}$ after intravenous cannulation. The cannula was kept patent with heparinized saline. An i.v. bolus injection of insulin (Insulin Actrapid, Novo Nordisk, Rüd, Norway; 0.10-0.15 IU/kg body weight) was then given at time 0 and the test was terminated after 90 min with a soft drink and a substantial meal. Blood samples were taken every $15 \mathrm{~min}$ from 0 to $90 \mathrm{~min}$, and at the time when each patient had symptoms of hypoglycemia $(\mathrm{H})$. Nadir plasma glucose was $<2.2 \mathrm{mmol} / \mathrm{l}$ in all subjects. The blood samples were analyzed for glucose, ACTH, cortisol, GH, leptin, and plasma catecholamines (CA; norepinephrine (NE) and epinephrine (E)). Serum samples were collected in tubes without anticoagulant, allowed to clot and centrifuged at 3000 r.p.m. for $10 \mathrm{~min}$ at room temperature. Serum was decanted, aliquots were frozen at $-20{ }^{\circ} \mathrm{C}$ until further use. Plasma samples were collected on ice into EDTA containing tubes (for ACTH analysis) or gluthation-EGTA tubes (for CA analysis), centrifuged at $4{ }^{\circ} \mathrm{C}$ at 3000 r.p.m. for $10 \mathrm{~min}$ and rapidly frozen at $-20{ }^{\circ} \mathrm{C}$ and $-80{ }^{\circ} \mathrm{C}$ for $\mathrm{ACTH}$ and $\mathrm{CA}$ respectively until assayed. In all subjects, 24-h urine sampling was performed the day prior to ITT.

\section{Biochemical measurements}

Catecholamine concentrations were assayed by high performance liquid-chromatography (HPLC) with a reverse phase column and a glassy carbon electrochemical detector (Waters, Milford, MA, USA), using a commercial kit from Chromsystems, München, Germany. In our hands, the intra- and interassay variations were, respectively, $10.7 \%$ and $14.5 \%$ for NE, and $23.2 \%$ and $10.5 \%$ for E.

Cortisol, ACTH, GH and leptin were determined by RIA (cortisol: Orion Diagnostica, Epsoo Finland; GH: Pharmacia, Uppsala, Sweden; ACTH: Nichols Institute, Nijmegen, The Netherlands; leptin: Linco Research Inc., St Charles, MO, USA). Luteinizing hormone (LH) and follicle-stimulating hormone (FSH) were measured by immunoassay (Access, Beckman Instruments, Chaska, MN, USA) while thyrotropin (TSH), free thyroxine $\left(\mathrm{FT}_{4}\right)$ and testosterone were measured by time-resolved fluoroimmunoassay (Wallac Oy, Turku, Finland). Estradiol was measured by Microparticle Enzyme Immunoassay (Abbott Laboratories, Abbott Parl, IL, USA). Plasma glucose was measured during the ITT with Accutrend Sensor
Glucose Stix and the values were verified with a photometric hexokinase method, Hitachi 917 (F Hoffman-La Roche Ltd, Basel, Switzerland).

\section{Statistics}

When comparing three groups of individuals, one-way ANOVA was followed by Scheffe's post hoc test for statistical significance. In the paired situation, multiple analyses of variance (ANOVA) were performed à priori and, if significant, a paired sample $t$-test was performed à posteriori. Relations between variables were tested using Pearson's correlation test and the
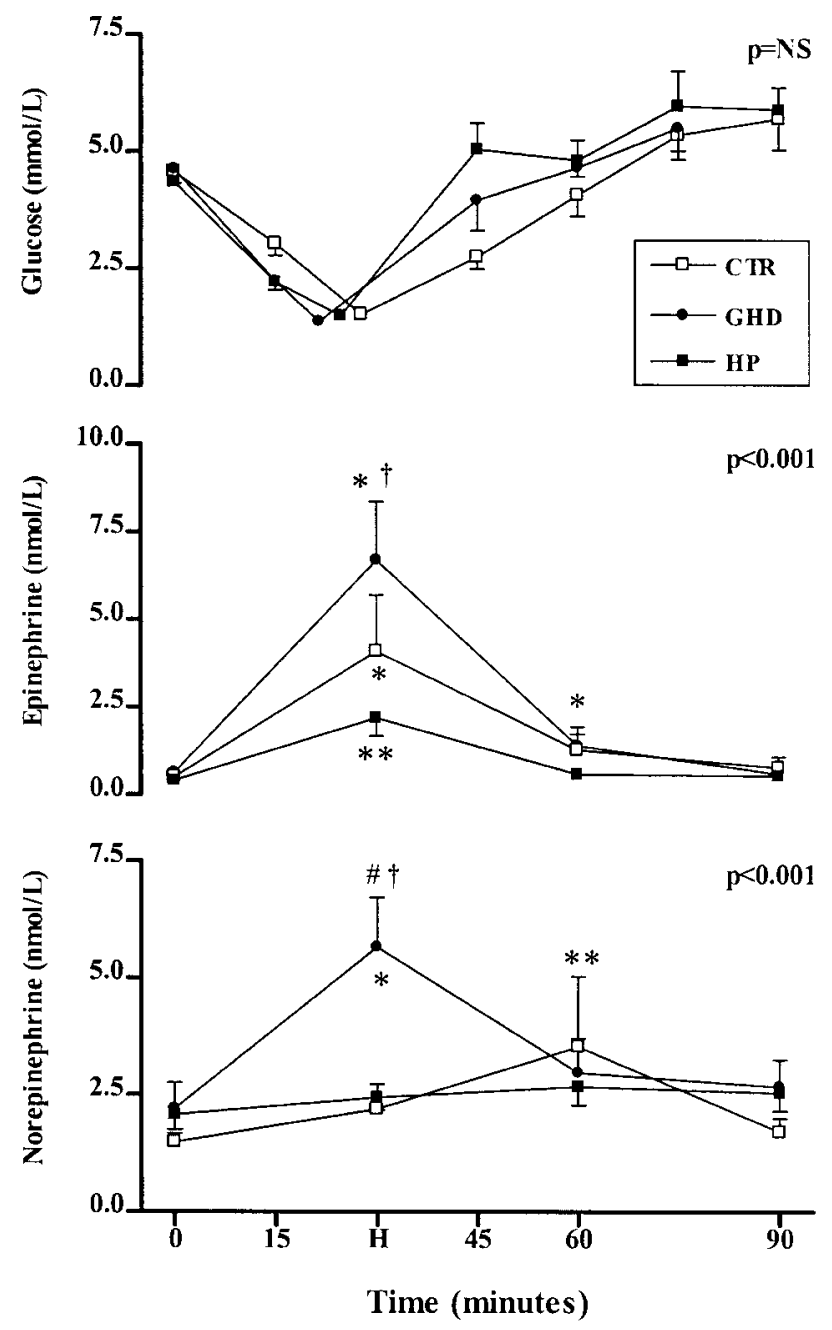

Figure 1 Insulin tolerance test: responses of plasma concentrations of glucose, epinephrine and norepinephrine in patients with hypopituitarism (HP), GH deficiency (GHD), and controls (CTR). The $P$ value in the upper right corner denotes the significance of the interaction between group and time from the ANOVA test. Data are given as means \pm S.E.M. ${ }^{*} P<0.05$, ${ }^{*} P<0.01$ compared with baseline; $\# P<0.05$ compared with controls; $\dagger P<0.01$ compared with HP. $\mathrm{H}=$ time of hypoglycemia. 
Table 2 Basal serum hormone concentrations and urinary cortisol of patients with hypopituitarism (HP), growth hormone deficiency (GHD) and controls. Data are means \pm S.E.M. $P$ values are from one-way ANOVA of three or more groups.

\begin{tabular}{|c|c|c|c|c|}
\hline & HP & GHD & Controls & $P$ \\
\hline Leptin (ng/ml) & $15.3 \pm 2.8$ & $15.3 \pm 4.7$ & $7.7 \pm 3.0$ & NS \\
\hline Leptin/BMl (ng/ml/kg $\left.{ }^{*} \mathrm{~m}^{2}\right)$ & $0.55 \pm 0.09$ & $0.64 \pm 0.18$ & $0.33 \pm 0.13$ & NS \\
\hline ACTH $(\mathrm{pmol} / \mathrm{l})$ & $3.9 \pm 0.5$ & $4.5 \pm 0.7$ & $4.8 \pm 1.1$ & NS \\
\hline Cortisol (nmol/l) & $193 \pm 32$ & $347 \pm 20^{\star \star}$ & $312 \pm 39^{*}$ & 0.01 \\
\hline Prolactin (mU/I) & $555 \pm 172$ & $351 \pm 163$ & $156 \pm 42$ & NS \\
\hline $\mathrm{FT}_{4}(\mathrm{pmol} / \mathrm{l})$ & $11.6 \pm 0.5$ & $14.2 \pm 1.0^{*}$ & $13.2 \pm 0.4^{*}$ & $<0.05$ \\
\hline $\mathrm{TSH}(\mathrm{mU} / \mathrm{l})$ & $1.3 \pm 0.4$ & $1.2 \pm 0.4$ & $1.2 \pm 0.3$ & NS \\
\hline $\mathrm{GH}(\mathrm{mU} / \mathrm{l})$ & $0.5 \pm 0.1$ & $0.3 \pm 0.0$ & $3.5 \pm .1 .6^{\star *}$ & $<0.01$ \\
\hline IGF-I (nmol/l) & $14.4 \pm 1.9$ & $18.3 \pm 2.7$ & $27.5 \pm 4.1^{\star \star}$ & $<0.01$ \\
\hline LH (U/I) & $4.1 \pm 2.0$ & $2.5 \pm 0.8$ & $4.3 \pm 2.2$ & NS \\
\hline FSH (U/I) & $8.7 \pm 5.5$ & $4.5 \pm 1.3$ & $4.0 \pm 1.0$ & NS \\
\hline Estradiol (nmol/l) & $0.2 \pm 0.1$ & $0.4 \pm 0.2$ & $0.3 \pm 0.1$ & NS \\
\hline Testosterone $(\mathrm{nmol} / \mathrm{l})$ & $10.4 \pm 2.9$ & $9.8 \pm 8.6$ & $17.0 \pm 3.7$ & NS \\
\hline Urinary cortisol (nmol/24 h) & $121 \pm 19$ & $257 \pm 50^{* *}$ & $292 \pm 70^{* *}$ & $<0.01$ \\
\hline
\end{tabular}

${ }^{\star} P<0.05,{ }^{* \star} P<0.01$ compared with $\mathrm{HP}$.

level of statistical significance was chosen as $P<0.05$ (two-sided) for all tests. Multiple regression analysis was performed to evaluate the influence of $\mathrm{FT}_{4}$, BMI and gender on leptin levels. Data are given as means \pm S.E.M. if not otherwise quoted.

\section{Results}

\section{Plasma glucose}

After an i.v. bolus injection of insulin, plasma glucose levels fell beneath the defined hypoglycemia threshold of $2.2 \mathrm{mmol} / \mathrm{l}$ in all groups (Fig. 1), with a nadir of $1.5 \pm 0.1 \mathrm{mmol} / \mathrm{l}$ after $21.5 \pm 1.5 \mathrm{~min}$ in GHD, $24.7 \pm 1.1 \mathrm{~min}$ in HP, and $27.8 \pm 1.4 \mathrm{~min}$ in CTR patients. There was a significant difference between hypoglycemia $(\mathrm{H})$ in the GHD and CTR groups $(P<0.02)$.

\section{ACTH, cortisol, GH and insulin-like growth factor-I (IGF-I)}

According to our definition of the three groups, 24-h excretion of cortisol, basal serum cortisol levels, and stimulated cortisol and ACTH levels were significantly lower in subjects with HP compared with both GHD and CTR patients (Tables 2 and 3), as were serum IGF-I and basal GH levels in GHD compared with CTR patients. Stimulated GH levels were significantly lower in both HP and GHD subjects compared with CTR (Table 3).

\section{Catecholamine levels}

Plasma epinephrine levels rose significantly from basal levels in all groups at the time of hypoglycemia $(\mathrm{H})$ (Fig. 1); the greatest response was seen in the GHD group, reaching levels that were significantly higher than in HP patients $(P<0.01)$. The $\Delta$-values at the time of hypoglycemia were significantly different between the groups $(1.781 \pm 0.493$ vs $6.066 \pm$ $1.633 \mathrm{nmol} / \mathrm{l}$ for HP and GHD respectively; $P<$ $0.01)$. The rise in plasma norepinephrine was delayed in the HP and CTR groups (60 min) and was of a lesser degree compared with the rise in epinephrine (Fig. 1), while the maximum rise in the GHD group was seen at the time of hypoglycemia, reaching significantly higher levels than in both the CTR $(P<0.05)$ and HP groups $(P<0.01)$. The $\Delta$-values at the time of hypoglycemia

Table 3 Insulin tolerance test: characteristics of responses in patients with hypopituitarism (HP), growth hormone deficiency (GHD) and controls (CTR). Results are means \pm S.E.M.

\begin{tabular}{|c|c|c|c|c|c|c|c|c|c|}
\hline \multirow[b]{2}{*}{ Time } & \multicolumn{3}{|c|}{ ACTH $(\mathrm{pmol} / \mathrm{l})$} & \multicolumn{3}{|c|}{ Cortisol (nmol/l) } & \multicolumn{3}{|c|}{ GH $(\mathrm{mU} / \mathrm{l})$} \\
\hline & HP & GHD & CTR & $\mathrm{HP}$ & GHD & CTR & $\mathrm{HP}$ & GHD & CTR \\
\hline $0 \min$ & $3.9 \pm 0.5$ & $4.5 \pm 0.7$ & $4.8 \pm 1.1$ & $193 \pm 32$ & $347 \pm 20 \dagger \dagger$ & $312 \pm 39 \dagger$ & $0.5 \pm 0.1$ & $0.3 \pm 0.0$ & $3.5 \pm 1.6 \dagger \dagger$ \\
\hline Hypoglycemia & $3.7 \pm 0.5$ & $4.9 \pm 1.4$ & $13.7 \pm 5.3+\dagger$ & $179 \pm 31$ & $341 \pm 40 \dagger \dagger$ & $329 \pm 35 \dagger$ & $0.8 \pm 0.3$ & $0.3 \pm 0.2 \#$ & $6.8 \pm 2.1 \dagger \dagger \dagger$ \\
\hline $60 \mathrm{~min}$ & $3.6 \pm 0.5$ & $10.8 \pm 3.2 \dagger \dagger$ & $24.2 \pm 7.3^{*} \dagger \dagger \dagger$ & $217 \pm 37$ & $600 \pm 49^{\star *}+\dagger \dagger$ & $579 \pm 24^{*}+\dagger$ & $1.5 \pm 0.4^{\star \star}$ & $1.8 \pm 1.0 \#$ & $44.2 \pm 13.5^{\star} \dagger \dagger \dagger$ \\
\hline $90 \mathrm{~min}$ & $2.4 \pm 0.3^{*}$ & $4.1 \pm 3.2 \dagger$ & $9.1 \pm 2.5 \dagger \dagger \dagger$ & $175 \pm 30$ & $502 \pm 34^{* \star}+\dagger \dagger$ & $535 \pm 35^{\star}+\dagger \dagger$ & $0.5 \pm 0.1$ & $0.9 \pm 0.5 \#$ & 19.3ะ6.3††† \\
\hline
\end{tabular}

${ }^{\star} P<0.05,{ }^{* \star} P<0.01$, compared with baseline; $\dagger P<0.05, \dagger \dagger P<0.01, \dagger \dagger \dagger P<0.001$, HP compared with at the same timepoint; \#P<0.05 CTR compared with at the same timepoint. 


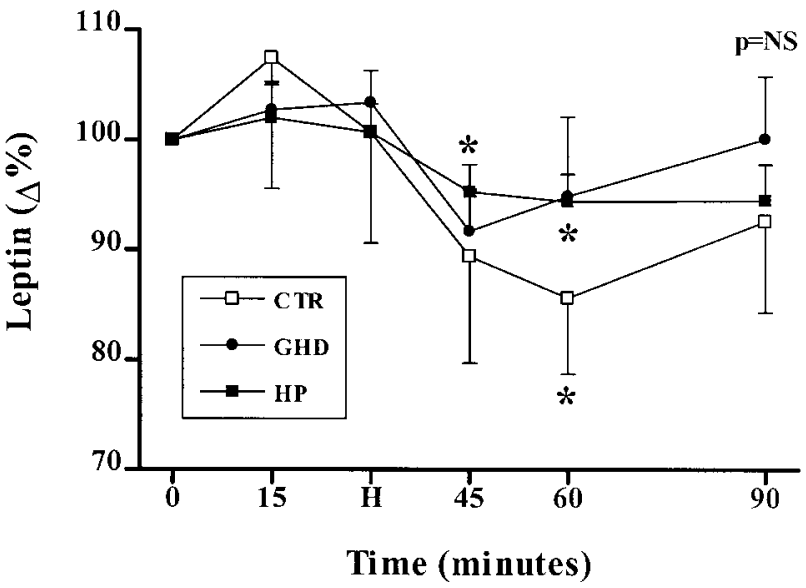

Figure 2 Insulin tolerance test: response of serum leptin concentration expressed as percentage change from baseline $(\Delta \%)$ in patients with hypopituitarism (HP), GH deficiency (GHD), and controls (CTR). Data are given as means \pm S.E.M. ${ }^{*} P<0.05$ compared with baseline (result of paired t-test). $\mathrm{H}=$ time of hypoglycemia.

were also significantly different in the GHD (3.563 $\pm 0.975 \mathrm{nmol} / \mathrm{l})$ compared with CTR (0.706士 $0.508 \mathrm{nmol} / \mathrm{l}, \quad P<0.05)$ and $\mathrm{HP}$ groups $(0.439 \pm$ $0.361 \mathrm{nmol} / \mathrm{l}, P<0.001)$.

\section{Leptin levels}

Basal leptin levels were not significantly different between the groups. When correcting basal leptin levels for gender, BMI and $\mathrm{FT}_{4}$ using a multiple regression model, no differences were found for basal leptin levels between the groups. Forty-five minutes after an i.v. bolus injection of insulin, there was a significant decrease in serum leptin levels in HP patients $(-4.7 \pm 2.5 \%, P<0.05)$, which was maintained after $60 \mathrm{~min}(-5.6 \pm 2.5 \%, P<0.05)$. In CTR patients, there was a significant decrease in serum leptin levels $60 \mathrm{~min}$ after i.v. insulin $(-14.4 \pm 6.9 \%$, $P<0.05)$. No significant response was observed in the GHD group; however 5 of 6 patients had decreased levels at 45 and 60 min (Fig. 2). When expressed in absolute values, and as a percentage decrease in serum leptin concentration, no differences between the groups over time were found (Figs 1 and 2). When normalized to BMI and expressed as leptin/BMI ratio $(\mathrm{ng} / \mathrm{ml} /$ $\mathrm{kg} \times \mathrm{m}^{2}$ ), similar results were obtained (data not shown).

\section{Discussion}

This study demonstrates for the first time the physiological effect of an endogenous catecholamine release on serum leptin levels in humans, investigated in subjects with distinct anterior pituitary function. Epinephrine is principally produced by the adrenal medulla, whereas circulating norepinephrine is released almost exclu- sively by the sympathetic nerves (25). In the present study, in HP and CTR patients the increase in norepinephrine was delayed and was of considerably lower magnitude compared with the epinephrine response, which had its maximum at the time of hypoglycemia. This is in accordance with earlier investigations on the insulin-induced stress response in healthy subjects (26). However, patients with isolated GHD had their signs and symptoms of hypoglycemia significantly earlier than controls, with a faster and more pronounced norepinephrine increase that accompanied the epinephrine increase; both responses were significantly higher than in the HP and CTR groups. These findings need to be elucidated with further studies.

In contrast with a recent investigation on stress response during surgery (24), we observed a significant negative effect on serum leptin levels 20 min after the onset of hypoglycemia, i.e. before the maximum cortisol increase. This suggests that principally adrenergic mechanisms and not alterations in the HPA axis are responsible for the decrease in serum leptin levels during acute endogenous stress. The activation of beta 3 receptors in the adipose tissue by epinephrine has been discussed as a possible mechanism (27-30).

Leptin levels have been shown to be inversely related to the HPA axis (6). In the present study, however, there were no obvious differences between patients with HP and isolated GHD or CTR, with regard to the decrease in serum leptin levels after catecholamine release. In accordance with this, a recent investigation did not demonstrate acute effects of a naloxone-induced ACTH release on plasma leptin levels (11). Further, the present data do not show divergent leptin responses between subjects with normal growth hormone responses (CTR) and patients with GHD or HP. This indicates that GH has no acute effects on short-term leptin regulation, as found by others $(13,15)$. We therefore suggest that the sympathetic adrenergic system might have an important role in the shortterm regulation of leptin levels in man, independent of anterior pituitary function.

The present study was designed as a pilot study and blood samples were obtained according to our routines for the ITT. Plasma catecholamines were determined at the moment of clinical signs and symptoms of hypoglycemia, with an average glucose nadir as low as $1.5 \mathrm{mmol} / \mathrm{l}$, which warranted a maximum stress response. Hypoglycemic symptoms arose significantly earlier in the GHD group compared with controls. As the objective was merely to demonstrate an adequate adrenergic response to ITT, as shown in earlier studies (26), catecholamine measurements were not obtained at close enough intervals to permit conclusions about possible differences in responses between the groups. Thus, the lower epinephrine peak in patients with HP might reflect either an asynchronous (accelerated or postponed) epinephrine response in this group 
compared with patients with GHD, or indicate a real difference in stress responses, dependent on anterior pituitary function. However, to elucidate the underlying mechanism, a study design with more frequent blood samples would be necessary.

Finally, as an interesting clinical aspect, patients with HP, although supposed to be adequately substituted in the thyrotrope hormone axis, had significantly lower free thyroxine levels within the normal range, compared with patients with isolated GHD and controls. This emphasizes the problem of determining optimal substitution doses based on clinical and laboratory assessment (31).

\section{Conclusions}

(i) An acute increase in endogenous circulating catecholamines is associated with a rapid decrease in serum leptin levels. (ii) Intact anterior pituitary function does not seem to be essential for this hitherto poorly understood mechanism.

\section{References}

1 Schwartz MW \& Seeley RJ. Neuroendocrine responses to starvation and weight loss. New England Journal of Medicine $19973361802-1811$.

2 Masuzaki H, Ogawa Y, Sagawa N, Hosoda K, Matsumoto T, Mise H et al. Nonadipose tissue production of leptin: leptin as a novel placenta-derived hormone in humans. Nature Medicine 19973 1029-1033.

3 Wiesner G, Vaz M, Collier G, Seals D, Kaye D, Jennings G et al. Leptin is released from the human brain: influence of adiposity and gender. Journal of Clinical Endocrinology and Metabolism 1999 $842270-2274$.

4 Considine RV, Sinha MK, Heiman ML, Kriauciunas A, Stephens TW, Nyce MR et al. Serum immunoreactive-leptin concentrations in normal-weight and obese humans. New England Journal of Medicine 1996334 292-295.

5 Saad MF, Damani S, Gingerich RL, Riad-Gabriel MG, Khan A, Boyadjian $\mathrm{R}$ et al. Sexual dimorphism in plasma leptin concentration. Journal of Clinical Endocrinology and Metabolism 199782 579-584.

6 Licinio J, Mantzoros C, Negrao AB, Cizza G, Wong M-L, Bongiorno PB et al. Human leptin levels are pulsatile and inversely related to pituitary-adrenal function. Nature Medicine $19973575-579$.

7 van Aggel-Leijssen DP, van Baak MA, Tenenbaum R, Campfield LA \& Saris WH. Regulation of average 24-h human plasma leptin level: the influence of exercise and physiological changes in energy balance. International Journal of Obesity and Related Metabolic Disorders 199923 151-158.

8 Saad MF, Riad-Gabriel MG, Khan A, Sharma A, Michael R, Jinagouda SD et al. Diurnal and ultradian rhythmicity of plasma leptin: effects of gender and adiposity. Journal of Clinical Endocrinology and Metabolism $1998 \mathbf{8 3} 453-459$.

9 Miell JP, Englaro P \& Blum WF. Dexamethasone induces an acute and sustained rise in circulating leptin levels in normal human subjects. Hormone and Metabolic Research $1996 \mathbf{2 8} 704-707$.

10 Schafroth U, Godang K, Ueland T, Berg JP \& Bollerslev J. Leptin levels in relation to body composition and insulin concentration in patients with endogenous Cushing's syndrome compared to controls matched for body mass index. Journal of Endocrinological Investigation 200023 349-355.

11 Wand GS \& Schumann H. Relationship between plasma adrenocorticotropin, hypothalamic opioid tone, and plasma leptin. Journal of Clinical Endocrinology and Metabolism $1998 \mathbf{8 3}$ 2138-2142.

12 Glasow A, Haidan A, Hilbers U, Breidert M, Gillespie J, Scherbaum WA et al. Expression of $\mathrm{Ob}$ receptor in normal human adrenals: differential regulation of adrenocortical and adrenomedullary function by leptin. Journal of Clinical Endocrinology and Metabolism $1998 \mathbf{8 3} 4459-4466$.

13 Wolthers T, Grofte T, Norrelund H, Poulsen PL, Andreasen F, Christiansen JS \& Jorgensen JOL. Differential effects of growth hormone and prednisolone on energy metabolism and leptin levels in humans. Metabolism $1998 \mathbf{4 7} 83-88$.

14 Gill MS, Toogood AA, Jones J, Clayton PE \& Shalet SM. Serum leptin response to the acute and chronic administration of growth hormone $(\mathrm{GH})$ to elderly subjects with $\mathrm{GH}$ deficiency. Journal of Clinical Endocrinology and Metabolism 199984 1288-1295.

15 Kousta E, Chrisoulidou A, Lawrence NJ, Al-Shoumer KAS, Parker KH, McCarthy MI \& Johnston DG. The circadian rhythm of leptin is preserved in growth hormone deficient hypopituitary adults. Clinical Endocrinology $1998 \mathbf{4 8} 685-690$.

16 Norrelund H, Gravholt CH, Englaro P, Blum WF, Rascher W, Chistiansen JS \& Jorgensen JO. Increased levels but preserved diurnal variation of serum leptin in GH-deficient patients: lack of impact of different modes of GH administration. European Journal of Endocrinology 1998138 644-652.

17 Janssen YJH, Frolich M, Deurenberg P \& Roelfsema F. Serum leptin levels during recombinant human GH therapy in adults with GH deficiency. European Journal of Endocrinology 1997137 650-654.

18 Pinkney JH, Goodrick SJ, Katz J, Johnson AB, Lightman SL, Coppack SW \& Mohamed-Ali V. Leptin and the pituitary-thyroid axis: a comparative study in lean, obese, hypothyroid and hyperthyroid subjects. Clinical Endocrinology $1998 \quad 49583-$ 588.

19 Valcavi R, Zini M, Peino R, Casanueva FF \& Dieguez C. Influence of thyroid status on serum immunoreactive leptin levels. Journal of Clinical Endocrinology and Metabolism 199782 1632-1634.

20 Pinkney JH, Coppack SW \& Mohamed-Ali V. Effect of isoprenaline on plasma leptin and lipolysis in humans. Clinical Endocrinology $199848407-411$.

21 Orban Z, Remaley AT, Sampson M, Trajanoski Z \& Chrousos GP. The differential effect of food intake and beta-adrenergic stimulation on adipose-derived hormones and cytokines in man. Journal of Clinical Endocrinology and Metabolism $1999 \mathbf{8 4}$ 2126-2133.

22 Zimmermann RC, Krahn L, Rahmanie N \& Sauer MV. Prolonged inhibition of presynaptic catecholamine synthesis does not alter leptin secretion in normal-weight men and women. Human Reproduction $199813822-825$.

23 Bottner A, Eisenhofer G, Torpy DJ, Ehrhart-Bornstein M, Keiser HR, Chrousos GP \& Bornstein SR. Lack of leptin suppression in response to hypersecretion of catecholamines in pheochromocytoma patients. Metabolism 199948 543-545.

24 Kain ZN, Zimolo Z \& Heninger G. Leptin and the perioperative neuroendocrinological stress response. Journal of Clinical Endocrinology and Metabolism $1999842438-2442$.

25 Cryer PE. Physiology and pathophysiology of the human sympathoadrenal neuroendocrine system. New England Journal of Medicine 1980303 436-444.

26 Blandini F, Martignoni E, Melzi DG, Biasio L, Sances G, Lucarelli C et al. Free plasma catecholamine levels in healthy subjects: a basal and dynamic study. The influence of age. Scandinavian Journal of Clinical and Laboratory Investigation 199252 9-17.

$27 \mathrm{Li} \mathrm{H}$, Matheny M \& Scarpace PJ. Beta 3-adrenergic-mediated suppression of leptin gene expression in rats. American Journal of Physiology 1997272 E1031-E1036.

28 Mantzoros CS, Qu D, Frederich RC, Susulic VS, Lowell BB, Maratos-Flier E \& Flier JS. Activation of beta3-adrenergic receptors suppresses leptin expression and mediates a leptinindependent inhibition of food intake in mice. Diabetes $1996 \mathbf{4 5}$ 909-914. 
29 Evans BA, Agar L \& Summers RJ. The role of the sympathetic nervous system in the regulation of leptin synthesis in C57BL/6 mice. FEBS Letters $1999 \mathbf{4 4 4} 149-154$.

30 Gettys TW, Harkness PJ \& Watson PM. The beta3-adrenergic receptor inhibits insulin-stimulated leptin secretion from isolated rat adipocytes. Endocrinology 1996137 4054-4057.

31 Ferretti E, Persani L, Jaffrain-Rea ML, Giambona S, Tamburrano G \& Beck-Peccoz P. Evaluation of the adequacy of levothyroxine replacement therapy in patients with central hypothyroidism. Journal of Clinical Endocrinology and Metabolism 199984 924-929.

Received 6 December 2000

Accepted 23 May 2001 